\title{
ABO Blood Group
}

National Cancer Institute

\section{Source}

National Cancer Institute. ABO Blood Group. NCI Thesaurus. Code C76245.

A blood group system based on recognition of inherited differences in the $\mathrm{H}$ antigen as expressed on erythrocytes. 